Marquette University

e-Publications@Marquette

$4-2009$

\title{
The Role of the Trivalent metal in an LDH: Synthesis, Characterization and Fire Properties of Thermally Stable PMMA/ LDH Systems
}

Charles Manzi-Nshuti

Marquette University

Dongyan Wang

Marquette University

Jeanne Hossenlopp

Marquette University, jeanne.hossenlopp@marquette.edu

Charles A. Wilkie

Marquette University, charles.wilkie@marquette.edu

Follow this and additional works at: https://epublications.marquette.edu/chem_fac

Part of the Chemistry Commons

\section{Recommended Citation}

Manzi-Nshuti, Charles; Wang, Dongyan; Hossenlopp, Jeanne; and Wilkie, Charles A., "The Role of the Trivalent metal in an LDH: Synthesis, Characterization and Fire Properties of Thermally Stable PMMA/LDH Systems" (2009). Chemistry Faculty Research and Publications. 11.

https://epublications.marquette.edu/chem_fac/11 


\title{
The Role of the Trivalent metal in an LDH: Synthesis, Characterization and Fire Properties of Thermally Stable PMMA/LDH Systems
}

\author{
Charles Manzi-Nshuti \\ Department of Chemistry and Fire Retardant Research Facility, \\ Marquette University \\ Milwaukee, WI \\ Dongyan Wang \\ Department of Chemistry and Fire Retardant Research Facility, \\ Marquette University \\ Milwaukee, WI \\ Jeanne M. Hossenlopp \\ Department of Chemistry and Fire Retardant Research Facility, \\ Marquette University \\ Milwaukee, WI \\ Charles A. Wilkie \\ Department of Chemistry and Fire Retardant Research Facility, \\ Marquette University \\ Milwaukee, WI
}

\begin{abstract}
Two layered double hydroxides (LDHs), calcium aluminum undecenoate $\left(\mathrm{Ca}_{3} \mathrm{Al}\right)$ and calcium iron undecenoate $\left(\mathrm{Ca}_{3} \mathrm{Fe}\right)$, have been prepared by the co-precipitation method. XRD analysis of these $L D H s$


reveals that they are layered materials and FT-IR and TGA confirmed the presence of the undecenoate anions in the material produced. The PMMA composites were prepared by bulk polymerization and the samples were characterized by XRD, TEM, TGA and cone calorimetry. Both additives greatly enhance the thermal stability of PMMA, while the calcium aluminum $L D H$ gives better results when the fire properties were examined using the cone calorimeter.

\section{Introduction}

Many investigations have shown that inorganic hydroxide fillers, especially magnesium hydroxide (MH) and aluminum trihydrate (ATH) are environmentally friendly additives $[1,2]$. However, they have disadvantages, such as the need for quite high loadings and poor compatibility with the polymeric matrix, which degrade the mechanical properties [3]. The search for other inorganic hydroxide to substitute for existing metal hydroxides $(\mathrm{MH}, \mathrm{ATH})$ has been of current interest [4].

In previous observations on polymer-clay nanocomposite flammability using montmorillonite (MMT) as the nanodimensional material, it is observed that reduction in the peak heat release rate (PHRR) is dependent on the polymer matrix and the quality of the nano-dispersion. In the case of polystyrene (PS), polyamide-6 (PA-6) and ethylene vinyl acetate copolymer (EVA), the reduction in PHRR is quite significant, around 60\% [5]. However, in the case of poly(methyl methacrylate) (PMMA), only a modest reduction in PHRR, 30\%, can be achieved $[6,7]$. It was further observed that the typical small reduction in PHRR seems to be dependent on both the identity and amount of the surfactant $[8,9]$.

The small reductions in PHRR observed for MMT/PMMA systems triggered a search for new additives for this polymer. Layered double hydroxides (LDHs), also known as hydrotalcite-like materials, may be a good candidate for this, as the composition of the layers can be varied, which is not possible with an MMT-like material. This presents an advantage, since tuning the LDH may lead to enhancement in some properties, but a good understanding of the role of each component of the $\mathrm{LDH}$ is required for optimization of the properties.

Polymer Degradation and Stability, Vol. 94, No. 4 (April 2009): pg. 705-711. DOI. This article is (C) Elsevier and permission has been granted for this version to appear in e-Publications@Marquette. Elsevier does not grant permission for this article to be further copied/distributed or hosted elsewhere without the express permission from Elsevier. 
The LDH structure is described with the ideal formula $\left[\mathrm{M}_{1}^{\mathrm{II}}{ }_{x} \mathrm{M}_{x}^{\mathrm{III}}(\mathrm{OH})_{2}\right]_{\text {intra }}\left[\mathrm{A}_{x / m}{ }^{m} \cdot n \mathrm{H}_{2} \mathrm{O}\right]_{\text {inter }}$ inter, where $\mathrm{M}^{\mathrm{II}}$ is a divalent cation such as $\mathrm{Mg}, \mathrm{Co}, \mathrm{Ni}, \mathrm{Cu}$, or $\mathrm{Zn}$ and $\mathrm{M}^{\mathrm{III}}$ is a trivalent cation such as $\mathrm{Al}, \mathrm{Cr}, \mathrm{Fe}, \mathrm{V}$, or $\mathrm{Ga}$ with $\mathrm{A}_{x / m}{ }^{m-}$ an anion of charge $m$ such as $\mathrm{NO}_{3}{ }^{-}$, $\mathrm{CO}_{3}^{2}, \mathrm{Cl}, \mathrm{SO}_{4}^{2}, \mathrm{C}_{12} \mathrm{H}_{25} \mathrm{SO}_{4}$, various carboxylates, etc; intra and inter denote the intralayer domain and the interlayer space, respectively. The LDH structure consists of brucite-like layers constituted of edgesharing $\mathrm{M}(\mathrm{OH})_{6}$ octahedra [10].

Anionic guest entities, like monomers and polymers [11,12], functional biomolecules $[13,14]$, and complexes of reducible transition metals $[15,16]$ have been intercalated within an LDH matrix. LDH nanocomposites have found applications in mechanical strengthening $[11,12]$, as adsorbents [17], or magnetic nanostructures [15,16]. In contrast, their potential usage as fire retardants has not been widely explored.

In recent work on LDHs as fire retardants for polymers, it was observed that matching an LDH with a particular polymer is a key to use these nanomaterials effectively [18]. An Mg-Al LDH will disperse much better in a polar polymer, like PMMA, than in a non-polar polyethylene, polypropylene or polystyrene. This task is not simple, as there are many parameters to control: metals (divalent and trivalent), anion functional groups (carboxylate, solfonate, sulfate, phosphate, etc.), anion sizes, crystallite sizes, stoichiometry and the polymer. The variation of the divalent metal cation in an LDH has an influence dispersability and fire properties of the corresponding polymer (nano)composites [19]. Finally, the length of the carboxylate chain has been varied and the dispersability of the LDH and fire properties assessed with both PMMA and PS; the dispersion is much better with PMMA but there is still a substantial reduction in the peak heat release rate even with the LDH poorly dispersed in PS [20]. In this work, two trivalent metal ions, aluminum and iron, are used keeping the divalent metal and anion the same.

There are a few reports in the literature discussing the use of iron in the fire retardancy of polymers. Nangrani et al. [21] reported that ferric oxide actually increased the flammability of polycarbonate.

Polymer Degradation and Stability, Vol. 94, No. 4 (April 2009): pg. 705-711. DOI. This article is @ Elsevier and permission has been granted for this version to appear in e-Publications@Marquette. Elsevier does not grant permission for this article to be further copied/distributed or hosted elsewhere without the express permission from Elsevier. 
Whelan [22) investigated iron oxide as an effective synergist with halogens in halogen-containing nitrile polymers. Recently, Jiao et al. [4] reported that $\mathrm{EVA} /\left(\mathrm{Mg} / \mathrm{Al} / \mathrm{Fe}-\mathrm{CO}_{3}\right)$ composites containing a variable amount of $\mathrm{Fe}^{3+}$ ion obtained a $\mathrm{V}-0$ rating in the UL-94 protocol, while with $\mathrm{EVA} / \mathrm{MgAl}-\mathrm{CO}_{3}$, (an iron-free hydrotalcite), dripping occurred. The presence of iron as a substitutional impurity in MMT has been shown to lead to radical trapping reactions and a reduction in the PHRR at low amounts of clay [23]. Kong et al. have recently reported on a synthetic iron-containing MMT analog and found that the iron has a significant effect on the degradation and fire properties [24].

\section{Experimental}

\subsection{Materials}

The materials used in the synthesis of the layered double hydroxides were analytical grade, obtained from the Aldrich Chemical Co. These include 10-undecenoic acid, $\mathrm{Ca}\left(\mathrm{NO}_{3}\right)_{2} \cdot 4 \mathrm{H}_{2} \mathrm{O}, \mathrm{Al}\left(\mathrm{NO}_{3}\right)_{3} \cdot 9 \mathrm{H}_{2} \mathrm{O}$, $\mathrm{Fe}\left(\mathrm{NO}_{3}\right)_{3} \cdot 6 \mathrm{H}_{2} \mathrm{O}$, sodium hydroxide. Methyl methacrylate (MMA) and benzoyl peroxide (BPO) were used to prepare the polymer composites. MMA monomer was passed through an inhibitor remover column before use.

\subsection{Preparation of the $L D H s$}

The $\mathrm{Ca} / \mathrm{Al}$ and $\mathrm{Ca} / \mathrm{Fe}$ LDHs undecenoate were synthesized using the co-precipitation method following the literature procedure [25]. The preparation was performed in a nitrogen atmosphere to exclude CO2 from the LDHs: $2000 \mathrm{ml}$ of deionized water was boiled for $30 \mathrm{~min}$ while purging with nitrogen, then cooled to room temperature. In a $3 \mathrm{~L}$ three-neck flask was placed $900 \mathrm{ml}$ of the previously treated water, under a constant nitrogen flow. To this was added $50 \mathrm{~g}(0.27 \mathrm{~mol})$ of undecenoic acid and 5 min later, $11 \mathrm{~g}(0.27 \mathrm{~mol})$ of $\mathrm{NaOH}$. After the solution became colorless, the nitrate solution was prepared in separate container by dissolving $64 \mathrm{~g}(0.27 \mathrm{~mol})$ of calcium nitrate and $34 \mathrm{~g}(0.091 \mathrm{~mol})$ of aluminum nitrate in $450 \mathrm{ml}$ of previously boiled water. This solution was then added dropwise to the 10-undecenoate solution, maintaining the $\mathrm{pH}$ of the solution at $10.0 \pm 0.1$. The slurry was aged at $60^{\circ} \mathrm{C}$ for 2 days, and washed several times with

Polymer Degradation and Stability, Vol. 94, No. 4 (April 2009): pg. 705-711. DOI. This article is @ Elsevier and permission has been granted for this version to appear in e-Publications@Marquette. Elsevier does not grant permission for this article to be further copied/distributed or hosted elsewhere without the express permission from Elsevier. 
NOT THE PUBLISHED VERSION; this is the author's final, peer-reviewed manuscript. The published version may be accessed by following the link in the citation at the bottom of the page.

degassed deionized water and dried in a vacuum oven at $80{ }^{\circ} \mathrm{C}$ for a day to yield the desired calcium aluminum undecenoate $\mathrm{LDH}\left(\mathrm{Ca}_{3} \mathrm{Al}\right)$. $\mathrm{Ca}_{3} \mathrm{Fe}$ was obtained similarly, with iron nitrate replacing aluminum nitrate and this sample was aged at room temperature.

\subsection{Preparation of LDHs/PMMA nanocomposites}

The PMMA/LDHs nanocomposites were prepared by a two-stage process by in situ bulk polymerization as reported by Wang et al. [25] with minor modifications. Briefly, the appropriate LDH loading was combined with MMA, total weight $140 \mathrm{~g}$ in a $400 \mathrm{ml}$ beaker covered with aluminum foil to reduce volatilization, and the mixture was stirred vigorously for 1 day. Then, the initiator, BPO, $0.1 \%$ was added, and the mixture heated to $70{ }^{\circ} \mathrm{C}$ to pre-polymerize it. The viscous mixture was cooled until a critical viscosity was reached, and another portion of initiator, $0.1 \%(0.14 \mathrm{~g})$ was added to the viscous mixture, which was then heated to $120^{\circ} \mathrm{C}$ for $8 \mathrm{~h}$. At the end, the polymer was placed overnight in a vacuum oven at $100{ }^{\circ} \mathrm{C}$ to remove unreacted monomer and yield the LDH/PMMA nanocomposites. For the two types of LDHs prepared in this study, the LDH loadings used with PMMA were 1, 5, and $10 \%$. This two-stage process was also used for the preparation of the control PMMA sample.

\subsection{Determination of molecular weight by viscosity}

The molecular weight of PMMA used in this work was obtained from viscosity data. The results are an average of three determinations, and the Mark-Houwink constants were obtained from published data [26].

\subsection{Characterization}

Thermogravimetric analysis (TGA) was performed on an SDT 2960 (TA Instruments) at the $15 \mathrm{mg}$ scale under a flowing nitrogen atmosphere at a scan rate of $20^{\circ} \mathrm{C} / \mathrm{min}$. Temperatures are reproducible to $\pm 3{ }^{\circ} \mathrm{C}$, while the error on the fraction of non-volatile materials is $\pm 2 \%$. TGA was done in duplicate and the average values are reported. Fourier transform infrared (FT-IR) spectra of the solid materials were obtained using the ATR mode on a Nicolet Magna-IR

Polymer Degradation and Stability, Vol. 94, No. 4 (April 2009): pg. 705-711. DOI. This article is @ Elsevier and permission has been granted for this version to appear in e-Publications@Marquette. Elsevier does not grant permission for this article to be further copied/distributed or hosted elsewhere without the express permission from Elsevier. 
560 spectrometer operated at $1 \mathrm{~cm}^{-1}$ resolution in the $650-4000 \mathrm{~cm}^{-}$ ${ }^{1}$ region. X-ray diffraction (XRD) measurements of the LDHs were performed on a Bruker-Nonius APEX2 with CCD detector with $0.5 \mathrm{~mm}$ Monocap collimator and graphite monochromator with $\mathrm{Cu} \mathrm{K} \alpha$ generator $(\lambda=1.54078 \AA)$ from a sealed $X$-ray tube. The powder sample was prepared as a $0.3 \mathrm{~mm}$ ball using a small amount of mineral oil and was put on the top of $0.1 \mathrm{~mm}$ nylon pin. The data were collected at various $2 \theta$ values in $9^{\circ}$ increments using $180^{\circ} \Phi$ rotations. The polymeric samples were compression molded into $20 \mathrm{~mm} \times 15 \mathrm{~mm} \times 1 \mathrm{~mm}$ plaques for XRD measurements on a Rigaku Miniflex II X-ray diffractometer, scaning from $1^{\circ}$ to $10^{\circ}$ at $0.02^{\circ}$ step size.

Bright field transmission electron microscopy (TEM) images of the composites were obtained at $80 \mathrm{kV}$ with a Zeiss $10 \mathrm{c}$ electron microscope. The samples were ultramicrotomed with a diamond knife on a Riechert-Jung Ultra-Cut $\mathrm{E}$ microtome at room temperature to give $\sim 70 \mathrm{~nm}$ thick sections. These sections were transferred from a knifeedge to 600 hexagonal mesh $\mathrm{Cu}$ grids. Cone calorimeter measurements were performed on an Atlas CONE-2 according to ASTM $\mathrm{E} 1352$ at an incident flux of $50 \mathrm{~kW} / \mathrm{m}^{2}$, using a cone shaped heater; the exhaust flow was set at $24 \mathrm{~L} / \mathrm{s}$. The specimens for cone calorimetry were prepared by compression molding of the sample (about $30 \mathrm{~g}$ ) into $3 \times 100 \times 100 \mathrm{~mm}$ square plaques. Typical results from cone calorimetry are reproducible to within about $\pm 10 \%$; these uncertainties are based on many runs in which thousands of samples have been combusted [27].

\section{Results and Discussion}

XRD patterns of the two LDHs, $\mathrm{Ca}_{3} \mathrm{Al}$ and $\mathrm{Ca}_{3} \mathrm{Fe}$ are shown in Fig. 1. The layer structure of the $\mathrm{Ca}_{3} \mathrm{Al}$ is more pronounced as the diffraction peaks are more symmetrical and sharp. The $\mathrm{Ca}_{3} \mathrm{Fe}$ produced under similar condition is also a layered material, as noted from the presence of two other reflection peaks at equidistant $2 \theta$ values, but it was poorly crystallized, as noted from the asymmetric shape of the diffraction peaks. The basal spacing is about $3 \mathrm{~nm}$ for both LDHs, indicating that the undecenoate anions were successfully intercalated between the layers.

Polymer Degradation and Stability, Vol. 94, No. 4 (April 2009): pg. 705-711. DOI. This article is (C) Elsevier and permission has been granted for this version to appear in e-Publications@Marquette. Elsevier does not grant permission for this article to be further copied/distributed or hosted elsewhere without the express permission from Elsevier. 
Fig. 2 provides the TGA of $\mathrm{Ca}_{3} \mathrm{Al}$ and $\mathrm{Ca}_{3} \mathrm{Fe}$, in a nitrogen environment, run from 50 to $600^{\circ} \mathrm{C}$. Both materials show a mass loss below $150^{\circ} \mathrm{C}$, assigned to the loss of gallery water. DTA of both materials (Fig. 3 ) shows that this mass loss is endothermic, centered around $130^{\circ} \mathrm{C}$. When heated to higher temperature, several other events are visible in the TGA/DTG curves. The other events are probably due to the dehydroxylation of the layers and total decomposition of the materials; this is the normal observation for an LDH [28]. The loss of the organic moiety occurs earlier for $\mathrm{Ca} 3 \mathrm{Fe}$ compared to Ca3Al. This is shown by the sharp DTG peak around $425^{\circ} \mathrm{C}$ and an exothermic DTA event ( $\max 450^{\circ} \mathrm{C}$ ) for Ca3Fe while a similar event is observed at $475^{\circ} \mathrm{C}$ (DTG) and $492^{\circ} \mathrm{C}$ (DTA) for Ca3Al. The degradation of $\mathrm{Ca} 3 \mathrm{Fe}$ is complete earlier $\left(475^{\circ} \mathrm{C}\right)$ than that of Ca3Al $\left(513^{\circ} \mathrm{C}\right)$. The final mass remaining is $47 \%$ and $34 \%$ for Ca3Fe and Ca3Al, respectively. From calculations based on the amount of reagents used and expected LDH formulae, a final mass of $47 \%$ and $44 \%$ is expected for Ca3Fe and Ca3Al, respectively, which indicates that $\mathrm{Ca} 3$

Further characterization of the LDHs used FT-IR (Fig. 4). With both materials, the observed bands are characteristic of undecenoatecontaining LDHs, and the assignments of the various bands correlate very well to previous work on undecenoate-containing LDH with different divalent metals [19]. The carbonate anion, the usual contaminant of these materials, is not present as shown by the absence of a peak at $1360 \mathrm{cmAl}$ produced contains excess organic. -1 . An additional band, a sharp band around $1578 \mathrm{~cm}-1$ is also observed in these spectra and can be attributed to the asymmetric $\mathrm{UC}=0$ of a hydrogen-bonded carboxylic acid in the interlayer of the LDH material $[28,29]$. The intercalation of such free acid groups [30] is a general phenomenon when excess carboxylate anions are used in the exchange or preparation, even at such high $\mathrm{pH}$ [31]. Overall, XRD, TGA/DTA and FT-IR of these two LDHs confirm that layered materials, containing undecenoate anions intercalated in the gallery spacing of the LDHs, have been produced.

Polymer Degradation and Stability, Vol. 94, No. 4 (April 2009): pg. 705-711. DOI. This article is (C) Elsevier and permission has been granted for this version to appear in e-Publications@Marquette. Elsevier does not grant permission for this article to be further copied/distributed or hosted elsewhere without the express permission from Elsevier. 
Nanocomposites can be described as immiscible, intercalated or exfoliated depending on the type of dispersion of the polymer matrix in the layers of the nanomaterial. In an immiscible system, also called a micro composite, the polymer does not enter into the gallery space of the nanomaterial; this is a conventional composite. An intercalated nanocomposite is obtained when the polymer enters the gallery space and the registry between the layers is maintained. In an exfoliated system, also referred to as a delaminated system, excellent nanodispersion of the layered material into the polymer matrix is accompanied with a loss of the registry between the layers. Wideangle X-ray diffraction (XRD) and transmission electron microscopy (TEM) are the most commonly used methods to study the dispersion of the polymer matrix into the galleries of the inorganic material.

After bulk polymerization of MMA/LDH, the diffraction peaks disappeared at all loadings (1, 5, 10\%) and for both $\mathrm{Ca} 3 \mathrm{Al} /(\mathrm{Fig} .5)$ and Ca3Fe/composites (Fig. 6). Two extreme cases can explain the disappearance of the diffraction peaks in XRD: (1) complete exfoliation of the layers in the polymer matrix, and/or (2) disordering of the LDH layers within the polymer matrix with no change in the d-spacing. To obtain more insight into the morphology of the PMMA/LDHs, TEMs were obtained and are shown in Figs. 7 and 8.

The TEM images of PMMA/5\% $\mathrm{Ca}_{3} \mathrm{Fe}$ are shown in Fig. 7. The lower magnification image on the left shows agglomeration of smaller tactoids dispersed unevenly in the polymer matrix. At higher magnification, the tactoids are still seen grouped into a circular disk without the presence of individual layers; hexagonal platelets, typical of pristine LDH, are also observed. Overall, this TEM suggests poor dispersion of this LDH within the PMMA matrix. The TEM image of $\mathrm{PMMA} / 5 \% \mathrm{Ca}_{3} \mathrm{Al}$ on the other hand (Fig. 8) shows a different morphology. The low magnification image shows fair dispersion of the LDH within the polymer matrix. The higher magnification image reveals that the registry of some of the layers is maintained, but also individual exfoliated layers are visible. Overall, a mixed intercalatedexfoliated morphology is suggested.

The thermal degradation pathways of PMMA are well understood. When PMMA is heated, the first small mass loss observed

Polymer Degradation and Stability, Vol. 94, No. 4 (April 2009): pg. 705-711. DOI. This article is @ Elsevier and permission has been granted for this version to appear in e-Publications@Marquette. Elsevier does not grant permission for this article to be further copied/distributed or hosted elsewhere without the express permission from Elsevier. 
is due to cleavage of weak links, typically head-to-head linkages [32], followed by larger mass loss due to scission at the unsaturated ends formed through termination by disproportionation. The final main event is the random chain scission of the PMMA backbone [33].

The TGA and corresponding derivatized mass, DTG, curves of PMMA and its $\mathrm{Ca}_{3} \mathrm{Fe}$ composites heated in nitrogen from 100 to $600^{\circ} \mathrm{C}$ are shown in Figs. 9 and 10, respectively, and the TGA data (onset temperature of degradation, $T_{0.1^{\prime}}$ midpoint degradation temperature, $T_{0.5}$ and the char at $600^{\circ} \mathrm{C}$ ) are summarized in Table 1 . The presence of the LDH pushes the TGA curves of the composites to higher temperatures showing enhanced thermal stability relative to the pure polymer.

The composites and the control polymer all show the two main thermal events expected for PMMA. The normal first step of degradation of PMMA, due to weak linkages, is not clearly observed in these samples. The event attributed to the scission at the unsaturated chain end is less pronounced when the LDH is added to the PMMA matrix. The molecular weight of the control PMMA sample obtained by viscosity measurement was $336,600 \pm 8700$. It should be pointed out that other factors, like the molecular weight of the polymer in a PMMA/LDH system can also play an important role in the properties of the system. Work is underway to elucidate this possibility. The main degradation event, the random scission of the PMMA backbone, occurs at a higher temperature relative to the virgin polymer prepared under similar conditions. $T_{\text {max }}$ is around $400 \mathrm{n}{ }^{\circ} \mathrm{C}$ for all $\mathrm{PMMA} / \mathrm{Ca}_{3} \mathrm{Fe}$ composites while that for pure PMMA is at $373^{\circ} \mathrm{C}$.

The TGA and corresponding derivatized mass, DTG, curves of PMMA and its $\mathrm{Ca}_{3} \mathrm{Al}$ composites heated in nitrogen from 100 to $600^{\circ} \mathrm{C}$ are shown in Figs. 11 and 12, respectively, and the TGA data (onset temperature of degradation, $T_{0.1}$ midpoint degradation temperature, $T_{0.5}$ and the char at $600^{\circ} \mathrm{C}$ ) are summarized in Table 1. As the LDH loading is increased, the thermal stability of the composite is gradually enhanced. Also, as summarized in Table 1, the char obtained at the end of the experiment gradually increases, and the mass of the char agrees well with that expected based on the amount of LDH.

Polymer Degradation and Stability, Vol. 94, No. 4 (April 2009): pg. 705-711. DOI. This article is @ Elsevier and permission has been granted for this version to appear in e-Publications@Marquette. Elsevier does not grant permission for this article to be further copied/distributed or hosted elsewhere without the express permission from Elsevier. 
The main difference between the thermal behavior of $\mathrm{Ca}_{3} \mathrm{Al}$ and $\mathrm{Ca}_{3} \mathrm{Fe}$ is noted in the last step associated with random chain scission of the PMMA backbone. As the $\mathrm{Ca}_{3} \mathrm{Al}$ loading increases, both $T_{0.5}$ and $T_{\max }$ increase as the loading of the LDH increases while for the ironcontaining material, $T_{\max }$ does not depend upon loading of the $\mathrm{LDH}$ and $T_{0.5}$ is $12{ }^{\circ} \mathrm{C}$ higher at $1 \%$ loading compared to the aluminumcontaining system. Both additives, $\mathrm{Ca}_{3} \mathrm{Fe}$ and $\mathrm{Ca}_{3} \mathrm{Al}$, offer significant enhancement in thermal stability of the PMMA composites relative to the pure polymer.

The fire properties of the PMMA/LDH systems were measured by cone calorimetry. Important parameters obtained from such a test are: time to ignition, amount of smoke produced, average mass loss rate, total heat released, the heat release rate and especially its peak value (PHRR). The reduction in PHRR is important for fire safety, as PHRR represents the point in a fire where heat is likely to propagate further, or ignite adjacent objects [34].

Fig. 13 provides the HRR curves of PMMA and its $\mathrm{Ca}_{3} \mathrm{Fe}$ composites while Fig. 14 gives the HRR curves of PMMA/Ca ${ }_{3} \mathrm{Al}$ systems. The summary of the cone calorimetric data is provided in Table 2. Overall, increasing the additive loading from 1 to $10 \%$ enhances the fire properties of the composites, shown by a gradual decrease in PHRR for all systems. The greatest reduction (54\%) is obtained with $\mathrm{PMMA} / 10 \% \mathrm{Ca}_{3} \mathrm{Al}$ sample. Bearing in mind that typical reductions observed for PMMA/MMT nanocomposites are usually in the range of $30 \%$ [7], these PMMA/LDH systems are very effective. Comparing the aluminum-containing samples with iron-containing samples, the former gives greater reductions in PHRR and burn for a longer time relative to the iron-containing systems and the virgin polymer. The TEM images of the two systems reveal relatively good dispersion for the $\mathrm{PMMA} / 5 \% \mathrm{Ca}_{3} \mathrm{Al}$ system while poor dispersion was noted for $\mathrm{PMMA} / 5 \% \mathrm{Ca}_{3}$ Fe sample. While one may be tempted to conclude that the metals play a role in the type of reduction obtained in these samples, the differences in the degree of dispersion may also explain the differences in the fire properties. Attempting to better 
disperse the iron-containing LDH in PMMA and comparing this new system with the PMMA/Ca ${ }_{3} \mathrm{Al}$ system should be the next challenging experiment in order to elucidate the dependence on the trivalent metal.

In previous work with various polymer/LDH systems, we have seen that there is not a good correlation between the nano-dispersion and cone calorimetry results. In several cases, it was observed that even a poorly dispersed LDH/polymer system gives as large a reduction in the PHRR as seen for a well-dispersed system [18-20]. This is completely unlike what has been seen for MMT systems where only well-dispersed clay gives a reduction in the PHRR. This continues to be a topic of interest in these laboratories.

The effectiveness of PMMA/10\% $\mathrm{Ca}_{3} \mathrm{Al}$ composites can be compared with fire behavior observed with polymer-MMT nanocomposites [6] where the nanocomposites burn for a longer time, but since the fuel is released slowly, the HRR stays low throughout the burning process. The finding that iron-containing LDH/PMMA system giving a higher PHRR relative to aluminum-containing LDH/ PMMA can, however, be correlated to the data reported by jiao et al. [4] where their $\mathrm{Mg} / \mathrm{Al} / \mathrm{Fe}-\mathrm{CO}_{3} \mathrm{LDHs}$ (sample containing a higher concentration of Fe3+) had a higher PHRR value relative to similar materials with lower iron content. From the same work, it was observed that the introduction of Fe3+ into the LDH prevented dripping in the $\mathrm{EVA} /(\mathrm{Mg} / \mathrm{Al} / \mathrm{Fe}-\mathrm{CO} 3 \mathrm{LDH})$ composites and improved the UL-94 ratings. Also, from Table 2, the iron-containing PMMA systems produce less smoke relative to the aluminum analogs at similar additive loading.

\section{Conclusions}

Two layered double hydroxides have been prepared and used to prepare thermally stable PMMA composites. We successfully prepared two layered materials intercalated with 10-undecenoate anions. The iron-containing LDH used in this investigation was less crystalline relative to its aluminum analog, but both materials give promising results when combined with PMMA. Greater reduction in PHRR (54\%) was recorded with $\mathrm{PMMA} / 10 \% \mathrm{Ca} 3 \mathrm{Al}$ sample with $\mathrm{PMMA} / 10 \% \mathrm{Ca} 3 \mathrm{Fe}$ giving $34 \%$. While the major difference between the two systems is

Polymer Degradation and Stability, Vol. 94, No. 4 (April 2009): pg. 705-711. DOI. This article is @ Elsevier and permission has been granted for this version to appear in e-Publications@Marquette. Elsevier does not grant permission for this article to be further copied/distributed or hosted elsewhere without the express permission from Elsevier. 
the metals, aluminum versus iron, it was noted that the dispersion was quite different, and the next challenge is to produce a well-dispersed iron-containing PMMA/LDH system and evaluate the corresponding fire and thermal properties to compare with this data.

Acknowledgments: This work was performed under the sponsorship of the US Department of Commerce, National Institute of Standards and Technology, Grant 60NANB6D6018.

\section{References}

[1] Lv JP, Qui IZ, Qu BJ. Nanotechnology 2004;15:1576.

[2] Fu MZ, Qu BJ. Polym Degrad Stab 2004;85:633.

[3] Wang ZZ, Qu BJ, Fan WC, Huang P. J Appl Polym Sci 2001;81:206.

[4] Jiao CM, Wang ZZ, Chen X, Hu Y. J Appl Polym Sci 2008;107:2626.

[5] Marosföi BB, Marosi G], Szep A, Anna P, Keszei S, Nagy B], et al. Polym Adv Technol 2006;17:255.

[6] Morgan AB. Polym Adv Technol 2006;17:206.

[7] Costache MC, Wang D, Heidecker MJ, Manias E, Wilkie CA. Polym Adv Technol 2006;17:272.

[8] Zhu J, Start P, Mauritz KA, Wilkie CA. Polym Degrad Stab 2002;77:253.

[9] Jash P, Wilkie CA. Polym Degrad Stab 2005;88:401.

[10] Hofmeister W, Von Platen H. Cryst Rev 1992;3:3; Bender-Koch C. Hyperfine Interact $1998 ; 117: 131$.

[11] Leroux F, Taviot-Gueho C. J Mater Chern 2005;15:3629.

[12] Darder M, Lopez-Blanco M, Aranda P, Leroux F, Ruiz-Hitzky E. Chern Mater 2005;17:1969.

[13] Ambrogi V, Fardella G, Grandolini G, Perioli L Int] Pharm 2001;220:22.

[14] Nakayama H, Wada N, Tsuhako M. Int J Pharm 2004;269:469.

[15] Tsyganok A, Sayari A. J Solid State Chern 2006;179:1830.

[16] Tarasov KA, O'Hare D, Isupov VP. Inorg Chern 2003;42:1919.

[17] Dékàny I, Berger F, Imrik K, Lagaly G. Colloid Polym Sci 1997;275:681.

[18] Nyambo C, Wang D, Wilkie CA. PolymAdvTechnol, in press.doi: 10.1001/pat.1272.

[19] Manzi-Nshuti C, Wang D, Hossenlopp JM, Wilkie CA. J Mater Chern 2008;18:3091-102.

[20] Nyambo C, Songtipya P, Manias E, Jimenez-Gasco MM, Wilkie CA. J Mater Chern. 2008; 18: 4827-38. doi: 10.1039/b806531d.

[21] Nangrani KJ, Wenger R, Daugherty PG. Plast Compd 1988;11:2729.

[22] Whelan WP. J Fire Ret Chern 1979;6:206.

[23] Zhu J, Uhl F, Morgan AB, Wilkie CA. Chern Mater 2001;13:4649-54.

Polymer Degradation and Stability, Vol. 94, No. 4 (April 2009): pg. 705-711. DOI. This article is (C) Elsevier and permission has been granted for this version to appear in e-Publications@Marquette. Elsevier does not grant permission for this article to be further copied/distributed or hosted elsewhere without the express permission from Elsevier. 
NOT THE PUBLISHED VERSION; this is the author's final, peer-reviewed manuscript. The published version may be accessed by following the link in the citation at the bottom of the page.

[24] Kong Q, Hu Y, Song L, Wang Y, Chen Z, Fan W. Polym Adv Technol 2006;19:463-7. Hu Y. Yang D. Song L. Polym Mater Sci Eng 2008;98:766.

[25] Wang G-A, Wang C-C, Chen C-c. Polymer 2005;46:5065.

[26] Kurata M, Tsunashima Y. In: Brandrup J, Immergut EH, Grulke EA, editors. Polymer handbook. 4th ed. New York: Wiley; 1999. p VII 183.

[27] Gilman JW, Kashiwagi T, Nyden M, Brown JET, Jackson CL, Lomakin S, et al. In: Al-Malaika S, Golovoy A, Wilkie CA. editors. Chemistry and technology of polymer additives. Oxford: Blackwell Scientific; 1999. p. 249.

[28] Xu ZP, Braterman PS, Yu K, Xu H, Wang Y, Brinker C]. Chern Mater 2004; $16: 2750$.

[29] Borja M, Dutta PK. J Phys Chern 1992;96:5434.

[30] Kloprogge JT, Frost RL. J Solid State Chern 1999;146:506.

[31] Xu ZP, Braterman PS, Seifollah N. Abstract. In: Proceedings of the 224th ACS National Meeting. Boston. MA. Aug. 18-22; 2002. Coli. 219.

[32] Holland B], Hay IN. Polym Degrad Stab 2002;77:435.

[33] Kashiwagi T, Inaba A, Brown JE, Hatada K, Kitayama T, Masuda E. Macromolecules 1986;19:2160.

[34] Babrauskas V, Peacock RD. Fire Safety J 1992;18:255.

Polymer Degradation and Stability, Vol. 94, No. 4 (April 2009): pg. 705-711. DOI. This article is @ Elsevier and permission has been granted for this version to appear in e-Publications@Marquette. Elsevier does not grant permission for this article to be further copied/distributed or hosted elsewhere without the express permission from Elsevier. 
NOT THE PUBLISHED VERSION; this is the author's final, peer-reviewed manuscript. The published version may be accessed by following the link in the citation at the bottom of the page.

\section{Appendix}

Figure 1: XRD patterns of $\mathrm{Ca}_{3} \mathrm{Al}$ and $\mathrm{Ca}_{3} \mathrm{Fe}$ LDHS-undecenoate

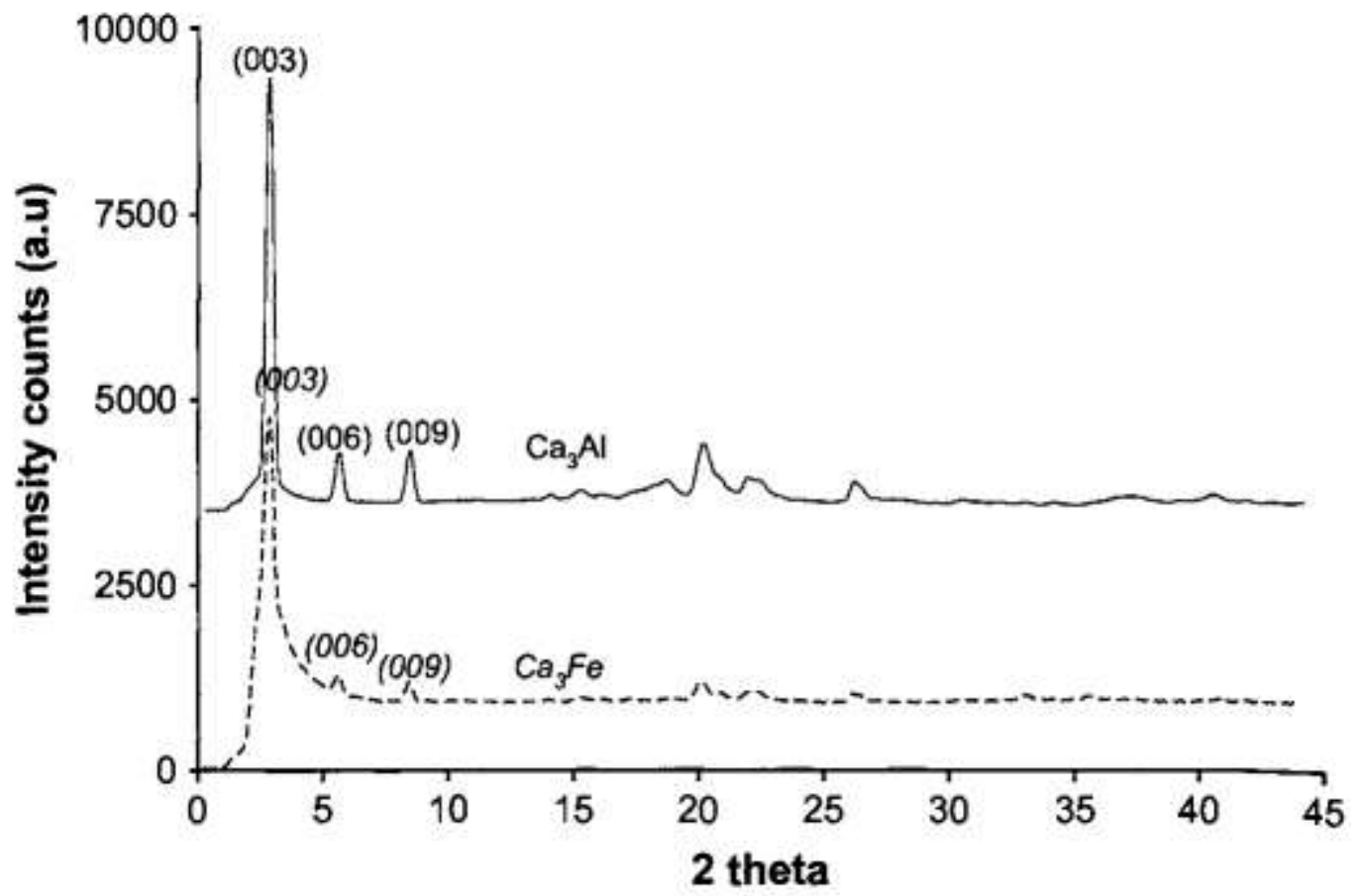


Figure 2: TGA and DTG profiles of undecenoate-LDHs. (A) $\mathrm{Ca}_{3} \mathrm{Fe} \mathrm{LDH}$; (B) $\mathrm{Ca}_{3} \mathrm{Al} \mathrm{LDH}$.
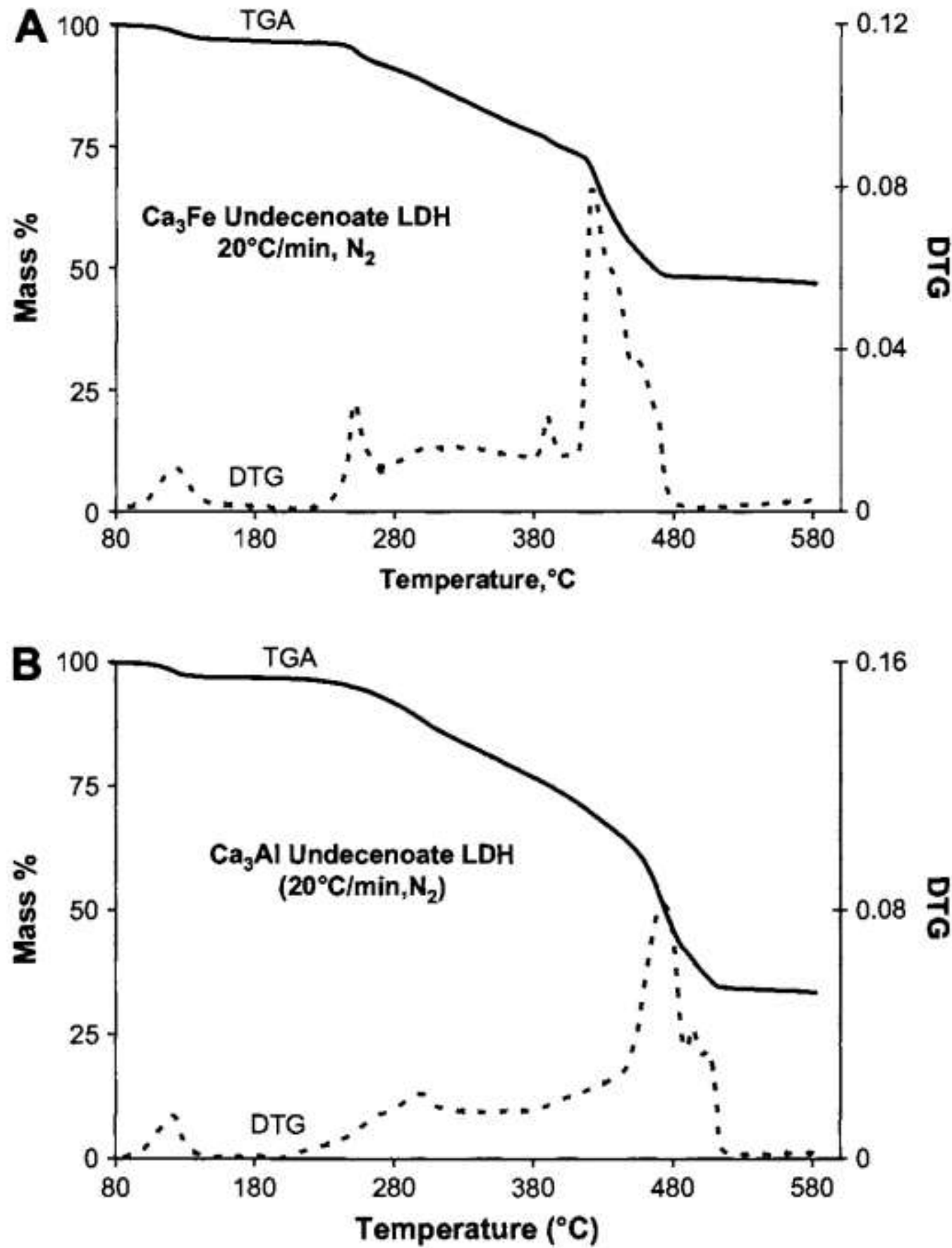

Polymer Degradation and Stability, Vol. 94, No. 4 (April 2009): pg. 705-711. DOI. This article is @ Elsevier and permission has been granted for this version to appear in e-Publications@Marquette. Elsevier does not grant permission for this article to be further copied/distributed or hosted elsewhere without the express permission from Elsevier. 
Figure 3: DTA profiles of $\mathrm{Ca}_{3} \mathrm{Al} \mathrm{LDH}$ (solid line) and $\mathrm{Ca}_{3} \mathrm{Fe} \mathrm{LDH}$ (dashed line).

\section{DTA Ca ${ }_{3} \mathrm{Al}$ LDH $\mathrm{Ca}_{3} \mathrm{Fe}$ LDH}

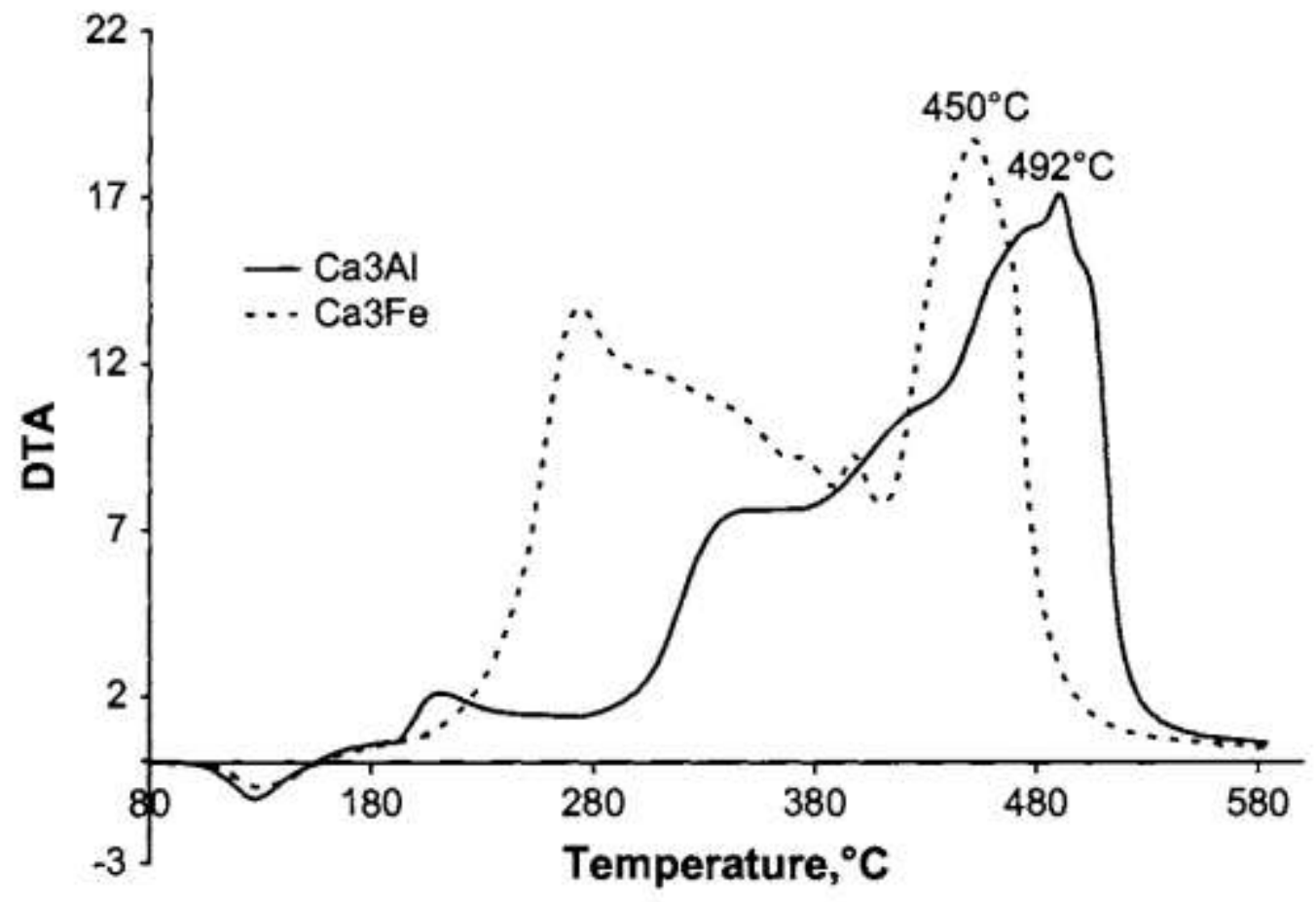


NOT THE PUBLISHED VERSION; this is the author's final, peer-reviewed manuscript. The published version may be accessed by following the link in the citation at the bottom of the page.

Figure 4: FT-IR of $\mathrm{Ca}_{3} \mathrm{Al} \mathrm{LDH}$ and $\mathrm{Ca}_{3} \mathrm{Fe} \mathrm{LDH}$ (ATR mode).

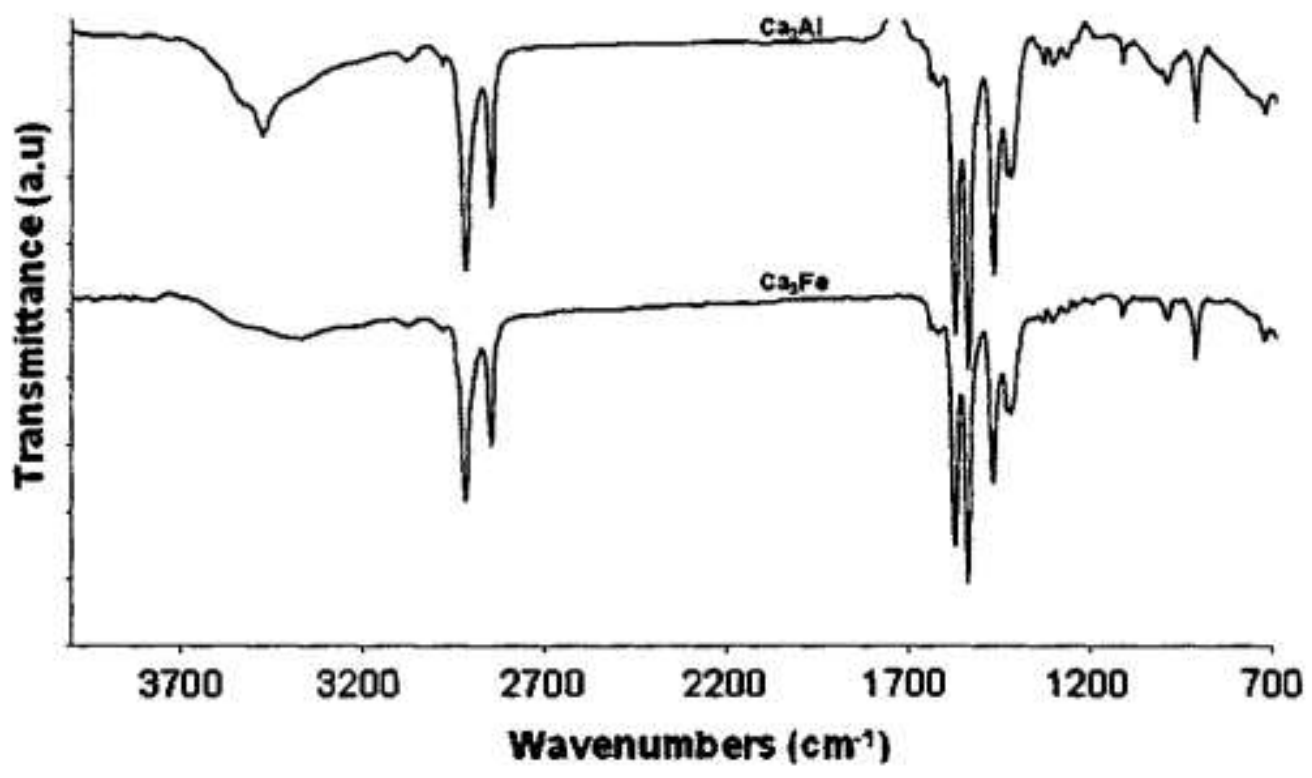

Polymer Degradation and Stability, Vol. 94, No. 4 (April 2009): pg. 705-711. DOI. This article is (C) Elsevier and permission has been granted for this version to appear in e-Publications@Marquette. Elsevier does not grant permission for this article to be further copied/distributed or hosted elsewhere without the express permission from Elsevier. 
NOT THE PUBLISHED VERSION; this is the author's final, peer-reviewed manuscript. The published version may be accessed by following the link in the citation at the bottom of the page.

Figure 5: XRD traces of $\mathrm{Ca}_{3} \mathrm{Al} L \mathrm{LDH}$ and its PMMA composites.

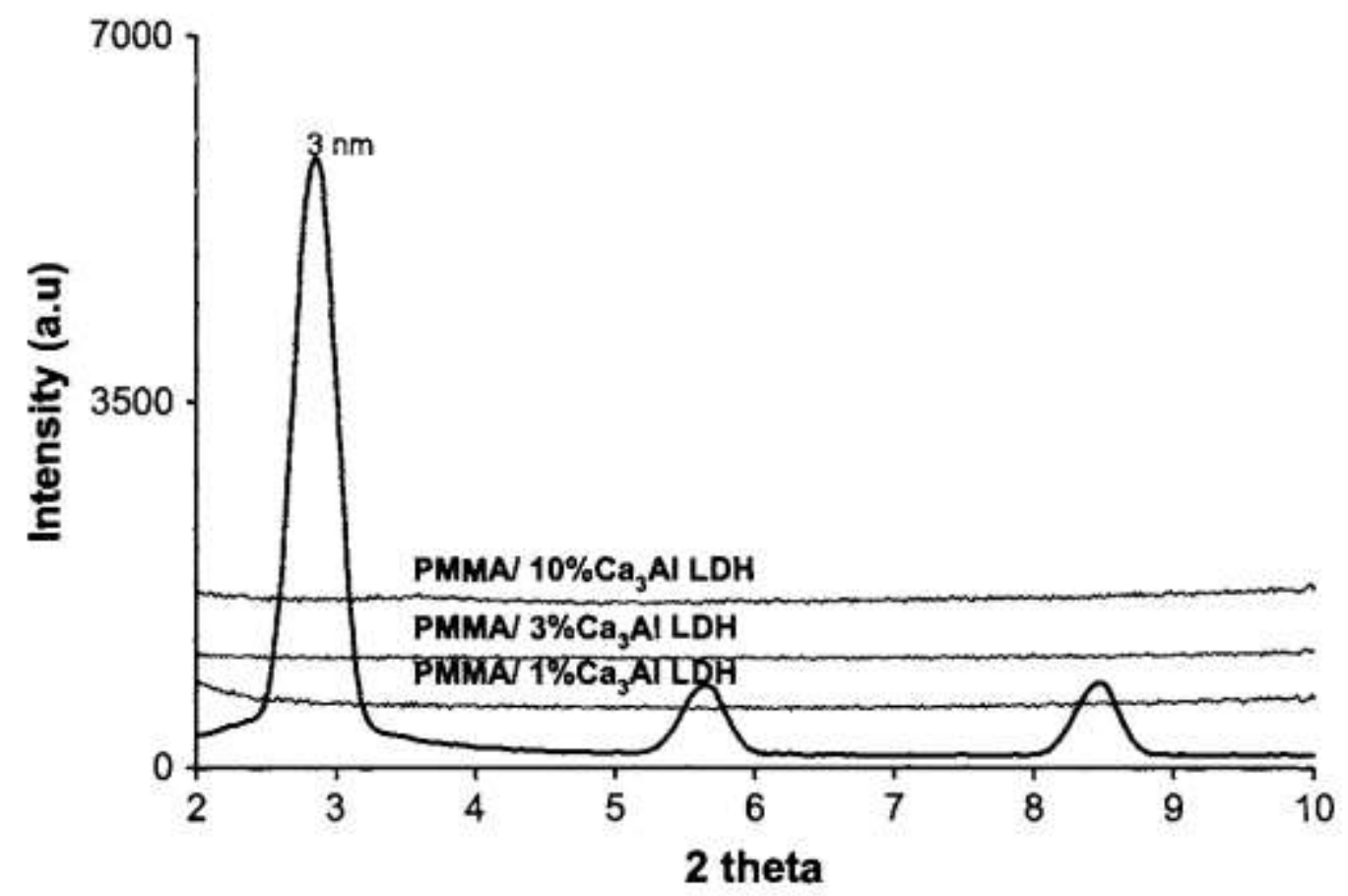

Polymer Degradation and Stability, Vol. 94, No. 4 (April 2009): pg. 705-711. DOI. This article is @ Elsevier and permission has been granted for this version to appear in e-Publications@Marquette. Elsevier does not grant permission for this article to be further copied/distributed or hosted elsewhere without the express permission from Elsevier. 
NOT THE PUBLISHED VERSION; this is the author's final, peer-reviewed manuscript. The published version may be accessed by following the link in the citation at the bottom of the page.

Figure 6: XRD traces of $\mathrm{Ca}_{3} \mathrm{Fe} \mathrm{LDH}$ and its PMMA composites.

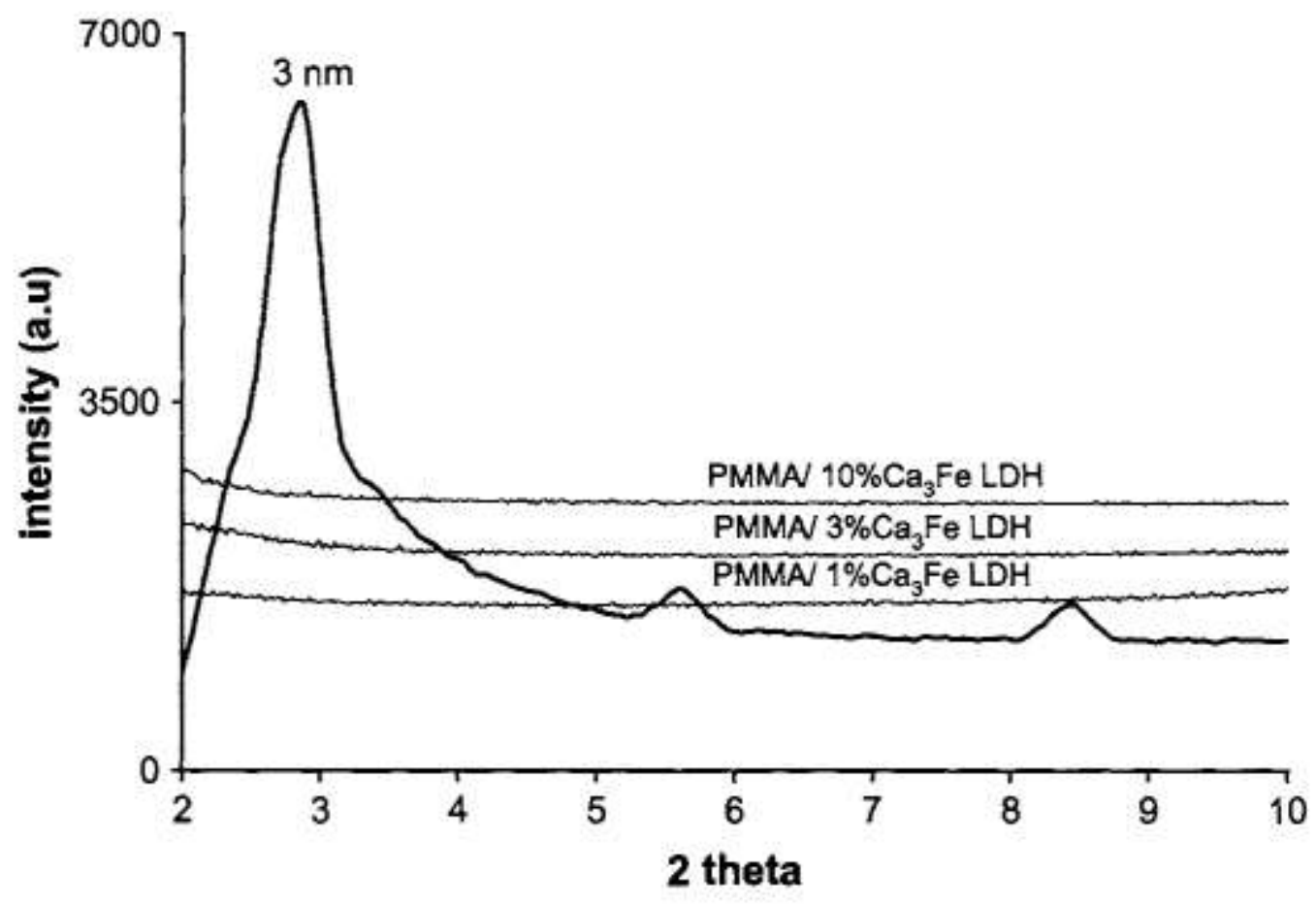

Polymer Degradation and Stability, Vol. 94, No. 4 (April 2009): pg. 705-711. DOI. This article is @ Elsevier and permission has been granted for this version to appear in e-Publications@Marquette. Elsevier does not grant permission for this article to be further copied/distributed or hosted elsewhere without the express permission from Elsevier. 
NOT THE PUBLISHED VERSION; this is the author's final, peer-reviewed manuscript. The published version may be accessed by following the link in the citation at the bottom of the page.

Figure 7: TEM image of PMMA/Ca ${ }_{3} \mathrm{Fe} L \mathrm{LDH}$ at different magnifications.
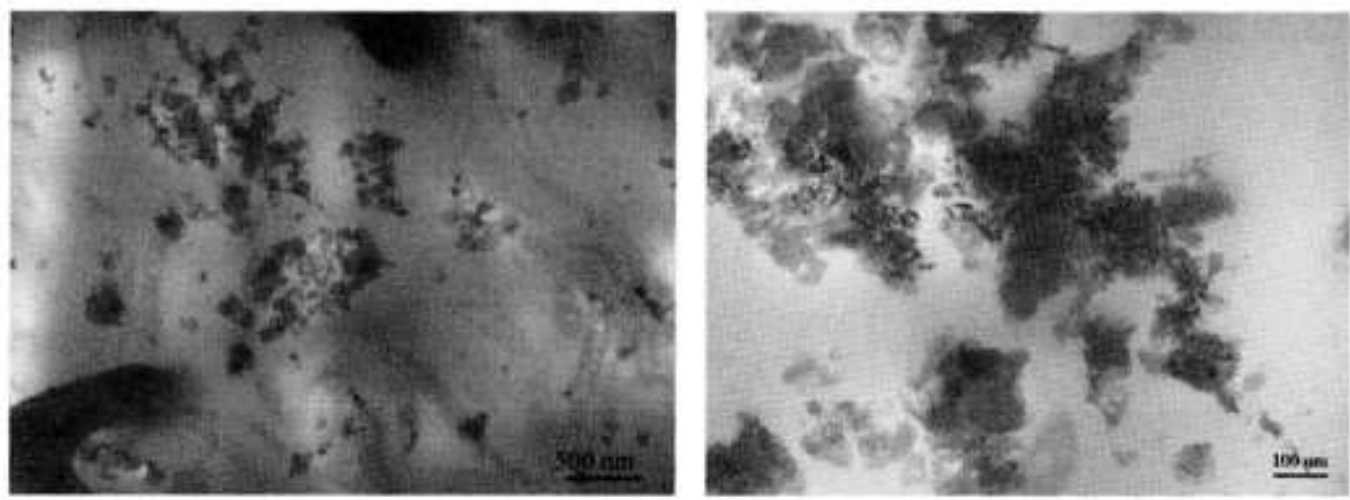

Polymer Degradation and Stability, Vol. 94, No. 4 (April 2009): pg. 705-711. DOI. This article is @ Elsevier and permission has been granted for this version to appear in e-Publications@Marquette. Elsevier does not grant permission for this article to be further copied/distributed or hosted elsewhere without the express permission from Elsevier. 
NOT THE PUBLISHED VERSION; this is the author's final, peer-reviewed manuscript. The published version may be accessed by following the link in the citation at the bottom of the page.

Figure 8: TEM image of PMMA/Ca ${ }_{3} \mathrm{Al} L D H$ at different magnifications.
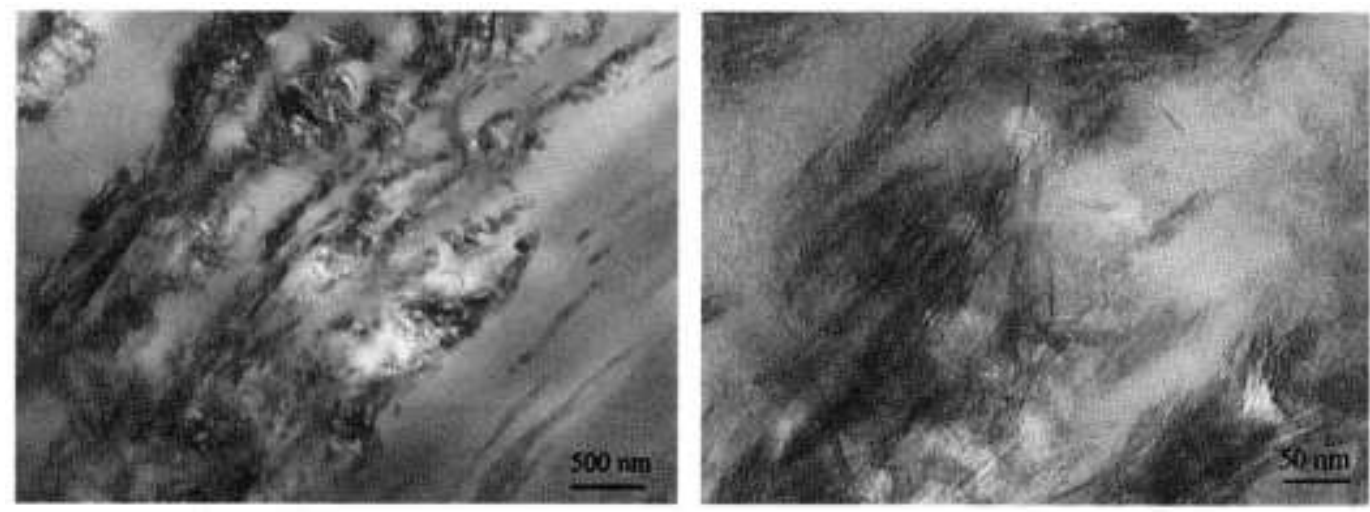

Polymer Degradation and Stability, Vol. 94, No. 4 (April 2009): pg. 705-711. DOI. This article is @ Elsevier and permission has been granted for this version to appear in e-Publications@Marquette. Elsevier does not grant permission for this article to be further copied/distributed or hosted elsewhere without the express permission from Elsevier. 
NOT THE PUBLISHED VERSION; this is the author's final, peer-reviewed manuscript. The published version may be accessed by following the link in the citation at the bottom of the page.

Figure 9: TGA curves of PMMA and its $\mathrm{Ca}_{3} \mathrm{Fe}$ undecenoate composites. (A) PMMA; (B) PMMA $/ 1 \% \mathrm{Ca}_{3} \mathrm{Fe}$; (C) PMMA $/ 5 \% \mathrm{Ca}_{3} \mathrm{Fe}$; (D) PMMA $/ 10 \%$ $\mathrm{Ca}_{3} \mathrm{Fe}$.

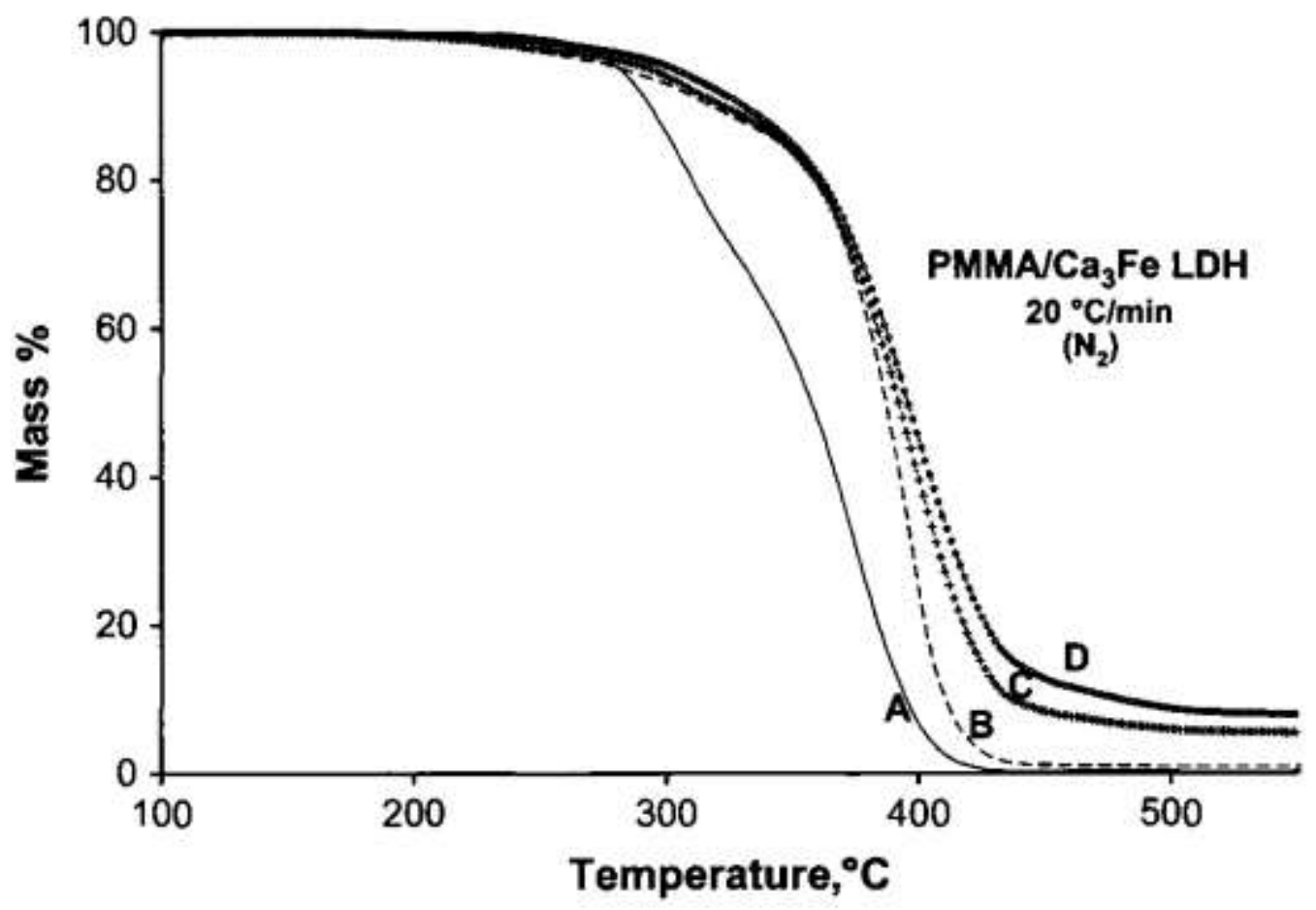


NOT THE PUBLISHED VERSION; this is the author's final, peer-reviewed manuscript. The published version may be accessed by following the link in the citation at the bottom of the page.

Figure 10: DTG of PMMA and its $\mathrm{Ca}_{3} \mathrm{Fe}$ composites.

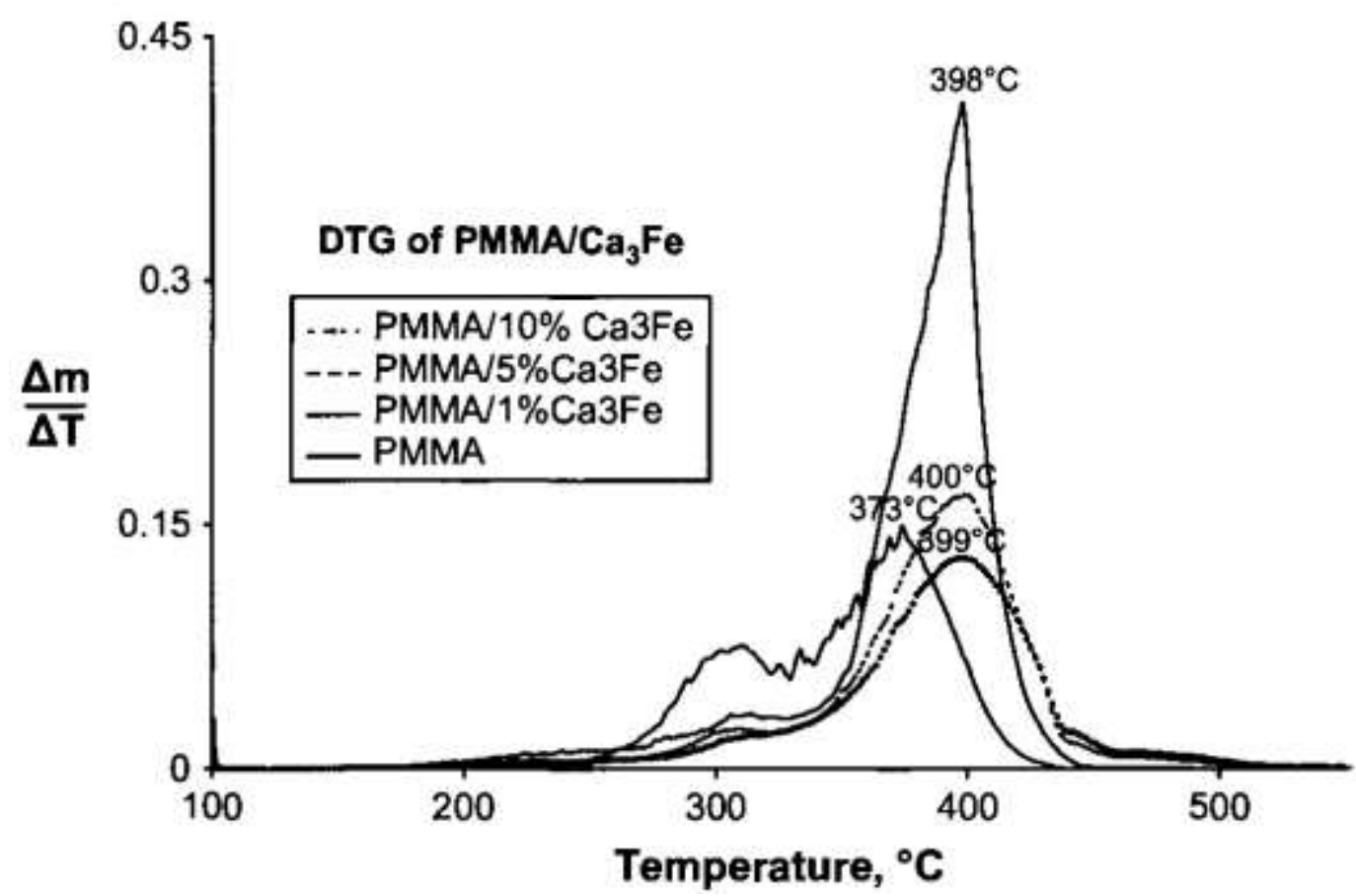


NOT THE PUBLISHED VERSION; this is the author's final, peer-reviewed manuscript. The published version may be accessed by following the link in the citation at the bottom of the page.

Figure 11:

Polymer Degradation and Stability, Vol. 94, No. 4 (April 2009): pg. 705-711. DOI. This article is @ Elsevier and permission has been granted for this version to appear in e-Publications@Marquette. Elsevier does not grant permission for this article to be further copied/distributed or hosted elsewhere without the express permission from Elsevier. 
NOT THE PUBLISHED VERSION; this is the author's final, peer-reviewed manuscript. The published version may be accessed by following the link in the citation at the bottom of the page.

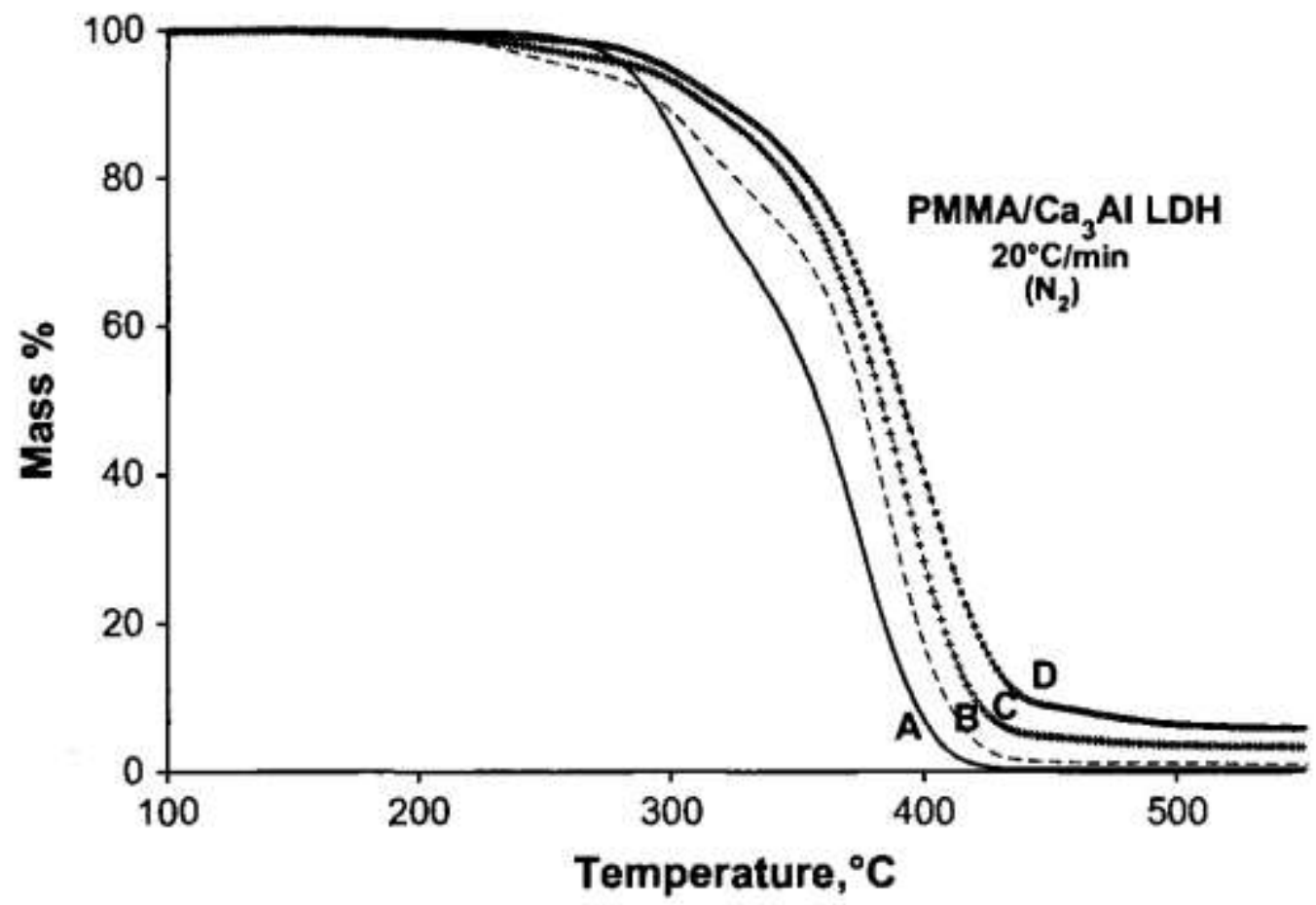

Polymer Degradation and Stability, Vol. 94, No. 4 (April 2009): pg. 705-711. DOI. This article is @ Elsevier and permission has been granted for this version to appear in e-Publications@Marquette. Elsevier does not grant permission for this article to be further copied/distributed or hosted elsewhere without the express permission from Elsevier. 
NOT THE PUBLISHED VERSION; this is the author's final, peer-reviewed manuscript. The published version may be accessed by following the link in the citation at the bottom of the page.

Figure 12: DTG of PMMA/Ca ${ }_{3} \mathrm{Al}$ systems.

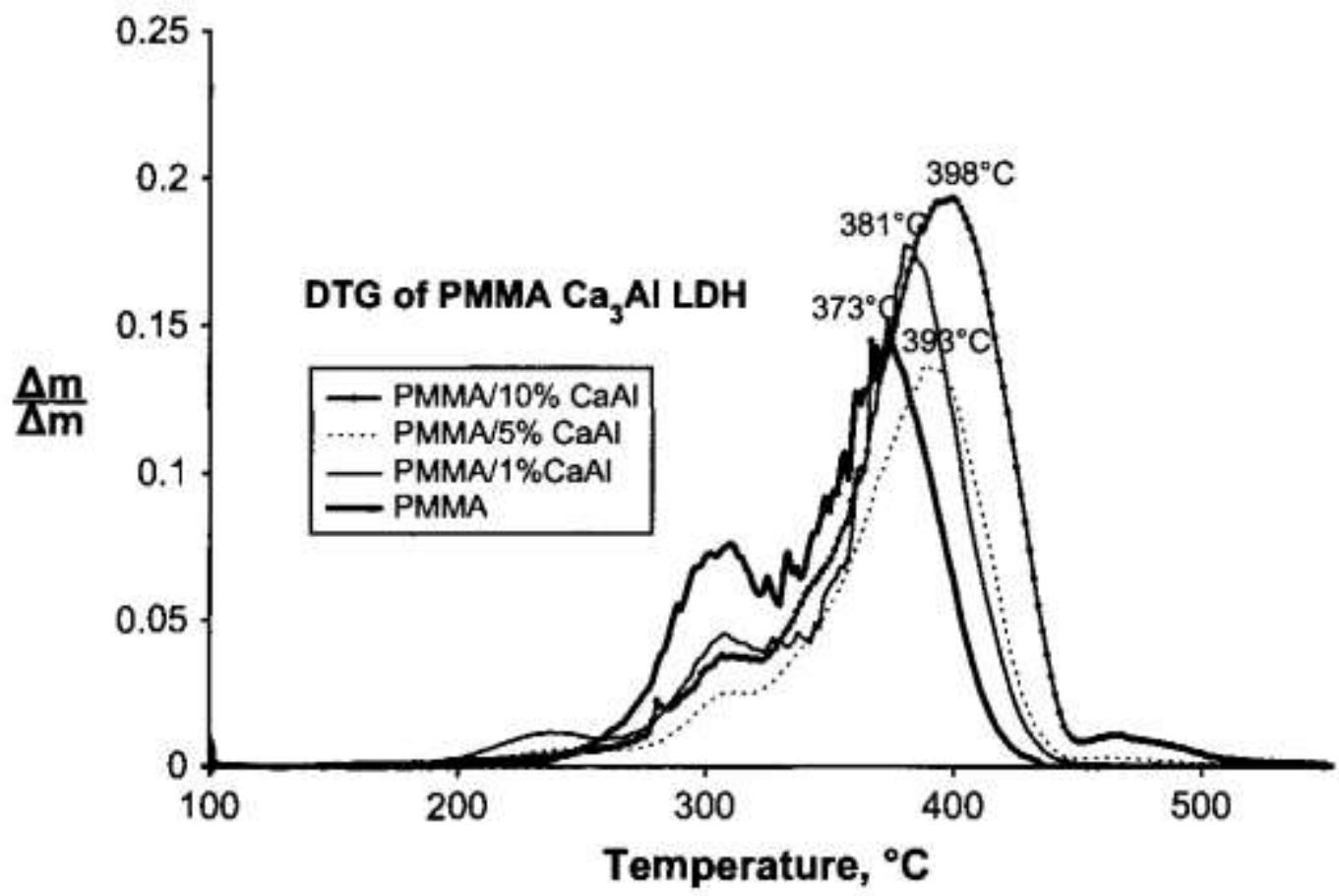

Polymer Degradation and Stability, Vol. 94, No. 4 (April 2009): pg. 705-711. DOI. This article is (C) Elsevier and permission has been granted for this version to appear in e-Publications@Marquette. Elsevier does not grant permission for this article to be further copied/distributed or hosted elsewhere without the express permission from Elsevier. 
NOT THE PUBLISHED VERSION; this is the author's final, peer-reviewed manuscript. The published version may be accessed by following the link in the citation at the bottom of the page.

Figure 13: HRR curves of PMMA and PMMA/Ca3Fe composites at 50 $\mathrm{kW} / \mathrm{m}^{2}$. (A) Virgin PMMA; (B) PMMA $/ 5 \% \mathrm{Ca}_{3} \mathrm{Fe}$ composites; (C) $\mathrm{PMMA} / 10 \% \mathrm{Ca}_{3} \mathrm{Fe}$ composites.

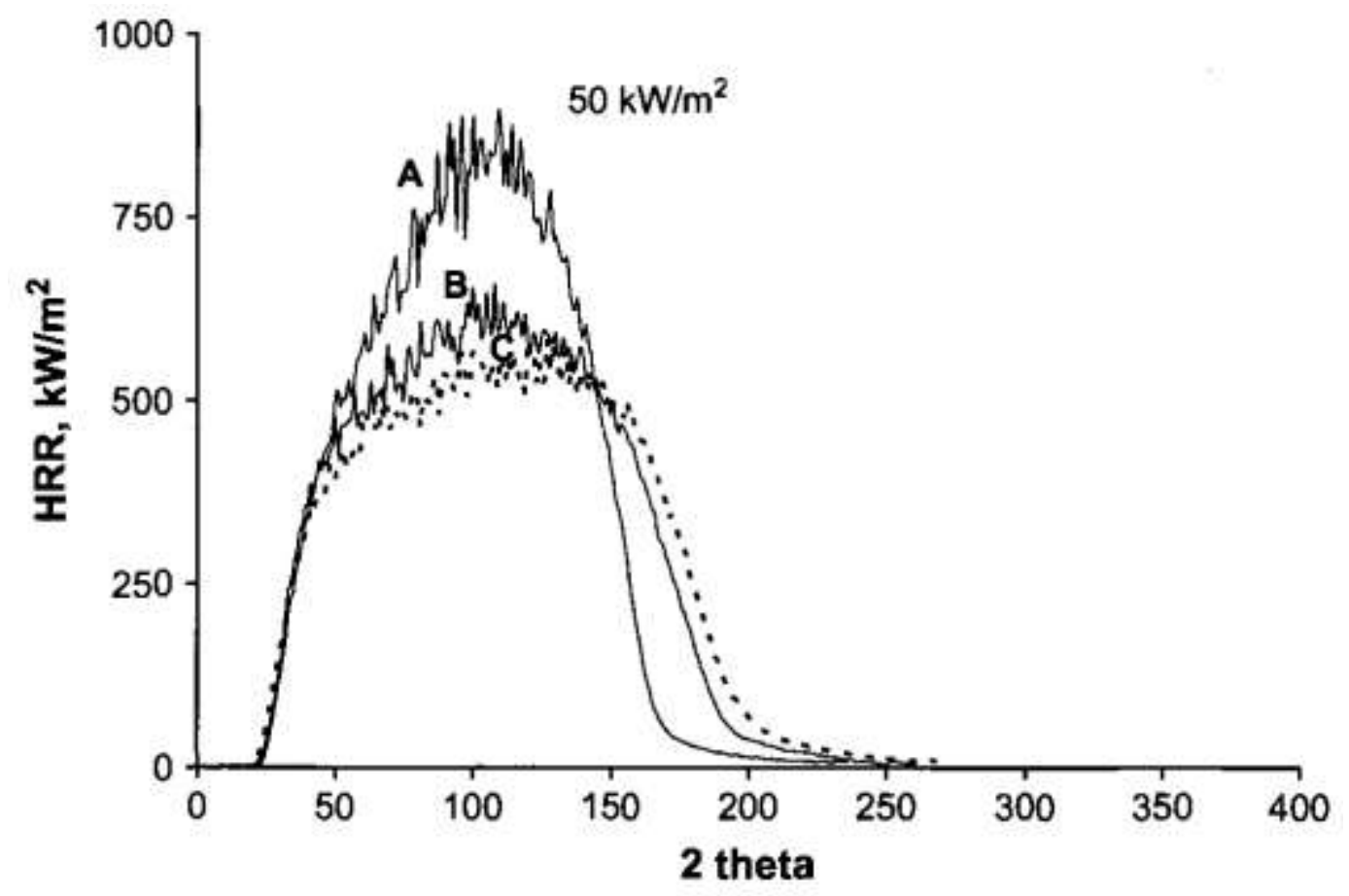


NOT THE PUBLISHED VERSION; this is the author's final, peer-reviewed manuscript. The published version may be accessed by following the link in the citation at the bottom of the page.

Figure 14: $H R R$ curves of PMMA and PMMA/Ca3Al composites at 50 $\mathrm{kW} / \mathrm{m}^{2}$. (A) Virgin PMMA; (B) PMMA/5\%Ca3Al composites; (C) PMMA $10 \%$ Ca3Al composites.

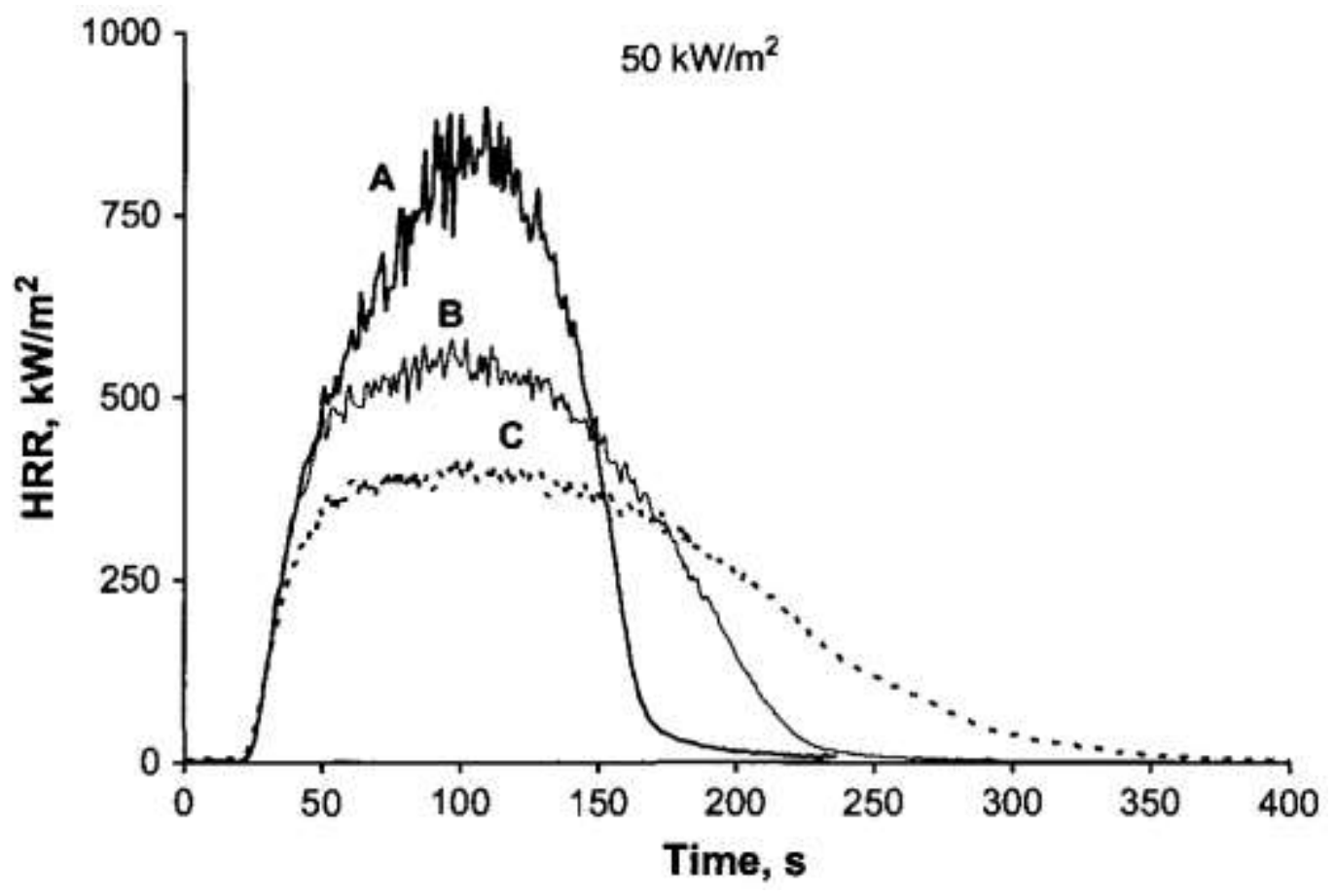


NOT THE PUBLISHED VERSION; this is the author's final, peer-reviewed manuscript. The published version may be accessed by following the link in the citation at the bottom of the page.

Table 1: TGA summary results of PMMA and its Ca3Al and Ca3Fe composites.

TGA summary data $\left(\mathrm{N}_{2}, 20^{\circ} \mathrm{C} / \mathrm{min}\right)$

\begin{tabular}{|c|c|c|c|c|c|}
\hline Sample & $T_{0.1}$ & $\Delta T$ & $T_{0.5}$ & $\Delta T$ & $\%$ Char at $600^{\circ} \mathrm{C}$ \\
\hline PMMA & 293 & NA & 357 & $\mathrm{NA}$ & 0 \\
\hline PMMA/Ca3 Al $1 \%$ & 296 & 3 & 374 & 17 & 1 \\
\hline $\mathrm{PMMA} / \mathrm{Ca}_{3} \mathrm{Al} 5 \%$ & 313 & 20 & 382 & 25 & 3 \\
\hline PMMA/Ca3Al 10\% & 321 & 28 & 390 & 33 & 5 \\
\hline $\mathrm{PMMA} / \mathrm{Ca}_{3} \mathrm{Fe} 1 \%$ & 315 & 22 & 386 & 29 & 1 \\
\hline $\mathrm{PMMA} / \mathrm{Ca}_{3} \mathrm{Fe} 5 \%$ & 322 & 29 & 392 & 35 & 4 \\
\hline $\mathrm{PMMA} / \mathrm{Ca}_{3} \mathrm{Fe} 10 \%$ & 330 & 37 & 395 & 38 & 6 \\
\hline
\end{tabular}

Note: $T_{0.1}$, temperature of $10 \%$ mass loss; $T_{0.5}$, temperature of $50 \%$ mass loss, $\Delta T$, difference between virgin polymer and the composite.

Table 2: Cone summary results of PMMA and its Ca3Al and Ca3Fe composites.

\begin{tabular}{llllll}
\hline Formulation & $\begin{array}{l}\text { PHRR }\left(\mathrm{kW} / \mathrm{m}^{2}\right) \\
(\% \text { reduction })\end{array}$ & $\begin{array}{l}\text { THR } \\
\left(\mathrm{MJ} / \mathrm{m}^{2}\right)\end{array}$ & $\begin{array}{l}\text { ASEA } \\
\left(\mathrm{m}^{2} / \mathrm{kg}\right)\end{array}$ & $\begin{array}{l}\text { AMLR } \\
\left(\mathrm{g} / \mathrm{s} \mathrm{m}^{2}\right)\end{array}$ & $t_{\text {ign }}(\mathrm{s})$ \\
\hline PMMA & $902 \pm 15(\mathrm{NA})$ & $79 \pm 0$ & $121 \pm 3$ & $27.0 \pm 0.5$ & $22 \pm 3.0$ \\
PMMA/Ca3Fe 1\% & $780 \pm 36(14)$ & $73 \pm 1$ & $137 \pm 7$ & $25.4 \pm 0.9$ & $20 \pm 2.0$ \\
PMMA/Ca3Fe 5\% & $655 \pm 20(27)$ & $73 \pm 0$ & $167 \pm 5$ & $21.8 \pm 0.5$ & $19 \pm 3.0$ \\
PMMA/Ca 3 Fe 10\% & $592 \pm 13(34)$ & $72 \pm 0$ & $196 \pm 13$ & $20.0 \pm 0.5$ & $15 \pm 0.9$ \\
PMMA/Ca Al 5\% & $597 \pm 17(36)$ & $75 \pm 2$ & $198 \pm 6$ & $19.1 \pm 0.9$ & $17 \pm 1.1$ \\
PMMA/Ca 31 Al 10\% & $418 \pm 4(54)$ & $74 \pm 0$ & $215 \pm 1$ & $12.9 \pm 0.6$ & $17 \pm 2.1$ \\
\hline
\end{tabular}

Note: PHRR, peak heat release rate; THR, total heat released; ASEA, average specific extension area (smoke); AMRL, average mass loss rate; $t_{\text {ign, }}$ time to ignition. 